\title{
PELATIHAN KADER POSYANDU LANSIA DAN SENAM LANSIA DI DESA GUWANG KECAMATAN SUKAWATI KABUPATEN GIANYAR
}

\author{
Muryani, Ni Made Sri ${ }^{1 *}$; Widyanata, Komang Agus Jerry ${ }^{1}$; Warditha, I Wayan ${ }^{1}$ \\ ${ }^{1}$ Akper Kesdam IX/Udayana \\ *Korespondensi: srimuryanimade@gmail.com
}

\begin{abstract}
Background: Aging is a process of disappearing slowly the ability of the network to repair, replace itself and maintain its normal structure and function. In an effort to improve the health of the elderly effectively, it needs to be supported by adequate human resource skills where one of them is an elderly Posyandu cadre. After training for elderly cadres and posyandu and elderly gymnastics, it is expected that the performance of the elderly posyandu cadres can be optimized so that they can provide better health services to the elderly. Method: This activity uses the Community Empowering approach with the method of lecturing, discussion and demonstration and this activity is divided into three stages, namely preparation, implementation, and evaluation. Result: The formation of elderly cadres, increasing knowledge of the elderly, elderly posyandu and the implementation of elderly gymnastics. Conclusion: Training of elderly posyandu cadres and elderly gymnastics has been carried out well in the form of selection of elderly cadres, implementation of elderly posyandu, and elderly gymnastics through the provision of materials and training for elderly posyandu. It is expected that Puskesmas officers will always supervise and evaluate the elderly posyandu activities in Guwang Village, so that the elderly was monitored for their health conditions.
\end{abstract}

Key words: cadres; elderly; posyandu

\begin{abstract}
ABSTRAK
Latar Belakang: Menua merupakan suatu proses menghilangnya secara perlahanlahan kemampuan jaringan untuk memperbaiki, mengganti diri dan mempertahankan struktur dan fungsi normalnya. Dalam upaya meningkatkan kesehatan lansia secara efektif, perlu di dukung oleh keterampilan sumber daya manusia yang memadai dimana salah satunya adalah kader posyandu lansia. Setelah diadakan pelatihan kader dan posyandu lansia serta senam lansia diharapkan kinerja kader posyandu lansia dapat dioptimalkan sehingga dapat memberikan pelayanan kesehatan yang lebih baik pada
\end{abstract}


lansia. Metode: Kegiatan ini menggunakan pendekatan Community Empowering (Pemberdayaan Masyarakat) dengan metode ceramah, diskusi, dan demonstrasi dan kegiatan ini dibagi menjadi tiga tahapan, yaitu persiapan, pelaksanaan, dan evaluasi. Hasil: Terbentuknya kader lansia, peningkatan pengetahuan lansia, posyandu lansia dan pelaksanaan senam lansia. Simpulan: Pelatihan kader posyandu lansia dan senam lansia sudah dilaksanakan dengan baik berupa pemilihan kader lansia, pelaksanaan posyandu lansia, dan senam lansia melalui pemberian materi dan pelatihan posyandu lansia. Diharapkan petugas Puskesmas selalu mengawasi dan mengevaluasi kegiatan posyandu lansia di Desa Guwang, sehingga para lansia terpantau kondisi kesehatannya.

Kata Kunci: kader; lansia; posyandu

\section{PENDAHULUAN}

Lanjut usia (lansia) dikatakan sebagai tahap akhir perkembangan pada dasar kehidupan manusia. Menua merupakan suatu proses menghilangnya secara perlahanlahan kemampuan jaringan untuk memperbaiki, mengganti diri dan mempertahankan struktur dan fungsi normalnya (Maryam, 2008). Pembinaan kesehatan lansia merupakan salah satu kegiatan yang harus terus digalakkan untuk mewujudkan lansia sejahtera, bahagia dan berdaya guna bagi kehidupan keluarga dan masyarakat sekitarnya.

Peningkatan usia harapan hidup ini tercermin dari semakin meningkatnya jumlah penduduk lanjut usia (lansia) dari tahun ke tahun. Populasi penduduk lansia di Asia dan Pasifik di perkirakan meningkat pesat dari 410 juta jiwa pada tahun 2007 menjadi 733 juta jiwa pada tahun 2005. Di Indonesia sendiri jumlah penduduk lansia pada tahun 2006 menjadi sekitar 17,48 juta jiwa pada tahun 2008 meningkat menjadi sekitar 19,50 juta jiwa. Angka ini sekitar 8,55 \% dari seluruh penduduk Indonesia (Badan Pusat Statistik, 2008).

Menurut Survei yang dilakukan pada tanggal 28 Maret 2015 didapatkan data jumlah lansia di Desa Guwang sebanyak 730 orang. Berdasarkan banyaknya populasi jumlah lansia di Desa Guwang, maka banyak pula permasalahan-permasalahan lansia khususnya masalah gizi dan kesehatan. Dalam upaya meningkatkan kesehatan lansia secara efektif, perlu di dukung oleh keterampilan sumber daya manusia yang memadai dimana salah satunya adalah kader posyandu lansia. Posyandu lansia adalah upaya kesehatan lansia yang mencakup kegiatan pelayanan kesehatan yang bertujuan untuk 
mewujudkan masa tua yang bahagia dan berdaya guna. Kader posyandu lansia bertugas membantu petugas puskesmas dalam melakukan pemeriksaan kesehatan lansia, antara lain: penilaian status gizi dan pemeriksaan tekanan darah.

Seorang kader haruslah mempunyai citra yang baik dimata masyarakat dan untuk meningkatkannya seorang kader harus memperhatikan: (a) meningkatkan kualitas diri sebagai orang yang dianggap masyarakat memberi informasi terkini tentang kesehatan. (b) melengkapi diri dengan keterampilan yang memadai dalam pelayanan di posyandu. (c) membuat kesan pertama yang baik dan memperhatikan citra yang positif. (d) menetapkan dan memutuskan perhatian lebih cermat pada kebutuhan masyarakat. (e) menampilkan diri sebagai bagian dari anggota masyarakat itu sendiri. (f) mendorong keinginan masyarakat untuk datang ke posyandu.

Guna meningkatkan pencitraan diri seorang kader, salah satunya dengan meningkatkan pengetahuan dan keterampilan kader. Peningkatan pengetahuan dan keterampilan ini dapat dilakukan dengan pendidikan dan pelatihan kader untuk meningkatkan kualitas kader dalam memberikan pengetahuan dan keterampilan. Berdasarkan hal tersebut, perlu diadakan pelatihan kader lansia untuk meningkatkan kualitas kader, serta posyandu lansia dan senam lansia untuk mengoptimalkan kesehatan lansia.

\section{METODE}

Kegiatan ini menggunakan pendekatan Community Empowering (Pemberdayaan Masyarakat). Masyarakat yang dimaksud adalah Kader Lansia dan Lansia Guwang. Pelatihan Kader untuk meningkatkan kualitas kader, serta posyandu lansia dan senam lansia untuk mengoptimalkan kesehatan lansia.

Kegiatan ini akan dilaksanakan pada bulan April 2015 dengan metode ceramah, diskusi, dan demonstrasi di Wantilan Desa Guwang. Kegiatan ini dibagi menjadi tiga tahapan, yaitu persiapan, pelaksanaan, dan evaluasi. Pada tahap persiapan dilakukan pemilihan kader lansia sesuai dengan kriteria yang telah ditentukan. Pada tahap pelaksanaan, dilakukan Pre Test sebelum diberikan pelatihan dan Post Test setelah pelatihan. Kegiatan posyandu lansia dan senam lansia juga dilakukan pada tahap 
pelaksanaan. Pada tahap evaluasi dilakukan saat berlangsungnya kegiatan posyandu lansia, yaitu untuk mengevaluasi kemampuan kader melaksanakan kegiatan posyandu lansia. Evaluasi kemampuan kader dapat dilihat dari nilai pre test dan post test kader, serta kemampuan kader saat menjalankan posyandu lansia dengan 5 meja.

\section{HASIL DAN PEMBAHASAN}

Hasil yang dapat dicapai dalam kegiatan pengabdian pelatihan kader posyandu lansia dan senam lansia ini adalah

1. Terbentuknya kader lansia yang terdiri dari lima orang yang merupakan perwakilan dari beberapa banjar yang ada di Desa Guwang untuk menjadi kader posyandu lansia.

2. Meningkatnya pengetahuan kader lansia melalui pemberian pelatihan kader lansia dan pendidikan kesehatan mengenai kesehatan lansia

3. Posyandu lansia yang juga dibantu oleh pihak puskesmas. Puskesmas bertugas pada meja IV yaitu pemberian tindakan perawatan medis dan lansia yang hadir dalam kegiatan posyandu ada 52 lansia.

4. Kegiatan senam lansia yang dipandu oleh petugas puskesmas dan kader lansia. Senam lansia diikuti oleh 52 orang lansia.

Pemilihan kader lansia disesuaikan dengan kriteria yang telah ditentukan dan rekomendasi dari Kepala Desa Guwang, maka dipilih 5 orang lansia yang merupakan perwakilan dari beberapa banjar yang ada di Desa Guwang untuk menjadi kader posyandu lansia. Setelah pemilihan kader lansia dilanjutkan kegiatan pelatihan kader posyandu lansia. Sebelum diberikan pelatihan kader lansia, terlebih dahulu kader diberikan pre test untuk mengetahui pemahaman kader tentang posyandu lansia. Setelah pre test, kader diberikan pelatihan posyandu lansia. Dalam pelatihan tersebut, kader diberikan tentang pelaksanaan sistem 5 meja dalam posyandu lansia, kesehatan lansia dan nutrisi pada lansia.

Setelah pelatihan, kader diberikan post test untuk mengetahui pemahaman kader tentang materi atau pelatihan yang sudah diberikan. Saat pemberian materi 
semua kader tampak mendengarkan penjelasan pemberi materi dengan baik, kader juga dapat mengikuti pelatihan dengan baik dan mengikuti sampai akhir pelatihan. Hasil pre test dan post test terdapat peningkatan pengetahuan kader lansia mengenai posyandu lansia, kesehatan lansia, dan nutrisi pada lansia, dimana rata-rata nilai pre test 38 (hanya mampu menjawab 5 pertanyaan dari 13 pertanyaan) dan nilai post test adalah 84 (dapat menjawab 11 pertanyaan dari 13 pertanyaan).

Saat pelaksanaan posyandu lansia, kader yang sudah mendapatkan pelatihan melaksanakan tugasnya masing-masing yaitu pada Meja I yang bertugas Bpk. I Made Wedayadnya, Meja II Bpk. A.A Gede Doble, Meja III Bpk. Made Warsi, Meja IV Ibu Mungkin, dan Meja V Ni Ketut Rasin. Selama pelaksanaan posyandu, selain kader dibantu juga oleh pihak puskesmas. Puskesmas bertugas pada meja IV yaitu pemberian tindakan perawatan medis. Lansia yang hadir dalam kegiatan posyandu ada 52 lansia. Kader lansia dapat menjalankan tugas mereka masing-masing dengan baik.

Senam lansia dipandu oleh petugas puskesmas dan kader lansia. Senam lansia diikuti oleh 52 orang lansia. Selama pelaksanaan senam lansia, semua lansia dapat mengikuti gerakan senam lansia dari awal sampai akhir senam. Lansia pun tidak ada keluhan setelah mengikuti senam lansia.

\section{SIMPULAN}

Kegiatan pengabdian pelatihan kader posyandu lansia dan senam lansia sudah dilakukan berupa pemilihan kader lansia, pelaksanaan posyandu lansia, dan senam lansia melalui pemberian materi dan pelatihan posyandu lansia. Kader posyandu dipilih berdasarkan rekomendasi dari Kepala Desa dan sesuai dengan kriteria yang telah ditentukan yaitu terpilih 5 orang lansia. Posyandu lansia dan senam lansia diikuti oleh 52 orang lansia, semua lansia dapat mengikuti posyandu dan senam lansia dengan baik dan tidak ada keluhan setelah mengikuti senam lansia.

Saran yang dapat diberikan berdasarkan kegiatan ini adalah diharapkan petugas Puskesmas selalu mengawasi dan mengevaluasi kegiatan posyandu lansia di Desa Guwang, sehingga para lansia terpantau kondisi kesehatannya dan Puskesmas juga selalu memberikan pelatihan dan penyegaran materi kepada kader lansia untuk 
meningkatkan pengetahuan dan pemahaman kader mengenai posyandu dan kesehatan lansia.

\section{DAFTAR PUSTAKA}

Depkes, RI. (2001). Pedoman Pelatihan Kader Kelompok Usia Lanjut Bagi Petugas Kesehatan. Jakarta: Direktorat Kesehatan Keluarga.

Depkes, RI. (2003). Pedoman Pelatihan Kader Kelompok Usia Lanjut Bagi Petugas Kesehatan. Jakarta: Direktorat Kesehatan Keluarga.

Maryam, Siti. . (2008). Mengenal Usia Lanjut dan Perawatannya. Jakarta: Salemba Medika.

Notoatmojdo, S. (2007). Kesehatan Masyarakat Ilmu dan Seni dan Pendidikan dan Perilaku Kesehatan. Jakarta: Rhineka Cipta.

Nugroho, W. (2008). Keperawatan Gerontik \& Geriatrik (Ketiga ed.). Jakarta: EGC.

Statistik, Badan Pusat. (2008). Penggolongan Pendapatan Penduduk. Jakarta: BPS. 